\title{
Rapid ore classification for real-time mineral processing optimisation at the Niederschlag multi-generation hydrothermal barite-fluorite vein deposit, Germany
}

\author{
Axel Müller ${ }^{1,2}$ (D) Henrik Ehle ${ }^{3}$ \\ Received: 30 July 2020 / Accepted: 7 December 2020 / Published online: 5 January 2021 \\ (C) The Author(s) 2021
}

\section{Introduction}

Fluorite is currently viewed as a critical raw material (CRM) by the European Commission (2017) as it is the main source of fluorine which is vital as a flux for metal ore smelting and the manufacture of hydrofluoric acid. In addition, it also contributes to the manufacture of fluorine-containing chemicals and their products. Due to supply risks and increasing industrial demand, investment in exploration and mining of European fluorite deposits has been encouraged to support European markets. The opening of the Niederschlag fluorite mine in the Erzgebirge, Germany, by Erzgebirgische Flussund Schwerspatwerke GmbH (EFS) in 2013, is a positive outcome of this initiative. EFS produces a fine-grained acid grade concentrate containing greater than $97 \% \mathrm{CaF}_{2}$.

The Niederschlag barite-fluorite mineralisation is a complex, multi-generation (Permian and Mesozoic) veintype deposit which has been modified by multiple syn- and post-genetic shearing and in the Paleogene-Neogene, local hydrothermal alteration and replacements caused by the emplacement of phonolite dykes and sills (Kuschka et al. 2002; Haschke et al. 2021). Each generation has its specific mineral paragenesis with distinctive mineral abundances and diversity, grain shapes and sizes and micro-scale mineral intergrowths. The combination of these complex

Editorial handling: H. Frimmel

Axel Müller

a.b.muller@nhm.ui.no

1 Natural History Museum, P.O. 1172 Blindern, N-0318 Oslo, Norway

2 Natural History Museum, Cromwell Road, London SW7 5BD, UK

3 Erzgebirgische Fluss- und Schwerspatwerke GmbH (EFS), D-09484 Oberwiesenthal, Germany features has greatly complicated the design and operation of mineral processing operations at the mine.

The major aim of this study was to establish criteria for the rapid 'real-time' identification of the main vein generation in the ore to allow crucial adjustments and refinements to be made to the processing flowsheet, to achieve the best possible quality of fluorite concentrate. In addition, the trace element compositions of fluorite from the main generations were determined by laser ablation inductively coupled plasma mass spectrometry (LA-ICPMS) to confirm that they are genetically different, i.e. formed during separate phases of hydrothermal alteration and mineralisation. This information could also be used to further develop the deposit model for Niederschlag to aid in exploration for near-mine extensions or similar deposits in the area or worldwide. The study does not aim to provide insights into methodologies for fluorite processing.

\section{Geology of the Niederschlag deposit}

The Niederschlag barite-fluorite deposit, which is part of the Niederschlag-Bärenstein ore district in the central Erzgebirge, is situated $12 \mathrm{~km}$ south of the German town of Annaberg-Buchholz, close to the border with the Czech Republic (Fig. 1). The major mineralised fault, which was named Magistralnaya by Russian geologists during $U$ mining operations (1948-1954), is c. $2.5 \mathrm{~km}$ long, up to $15 \mathrm{~m}$ wide, strikes NNW-SSE and dips $80^{\circ}$ towards WSW (Fig. 2). The Niederschlag deposit hosts 3.1 Mt of raw ore reserves containing $1.34 \mathrm{Mt}$ of $\mathrm{CaF}_{2}$ (Kuschka et al. 2002).

Vertically, the deposit can be divided into an upper part, which hosted the $U$ mineralisation (exploited), and a lower part from the 765-m level downwards, in which the $U$ mineralisation disappeared (Kuschka et al. 2002). The lower part of the Magistralnaya is the target for fluorite mining today. The mineralisation was formed from 


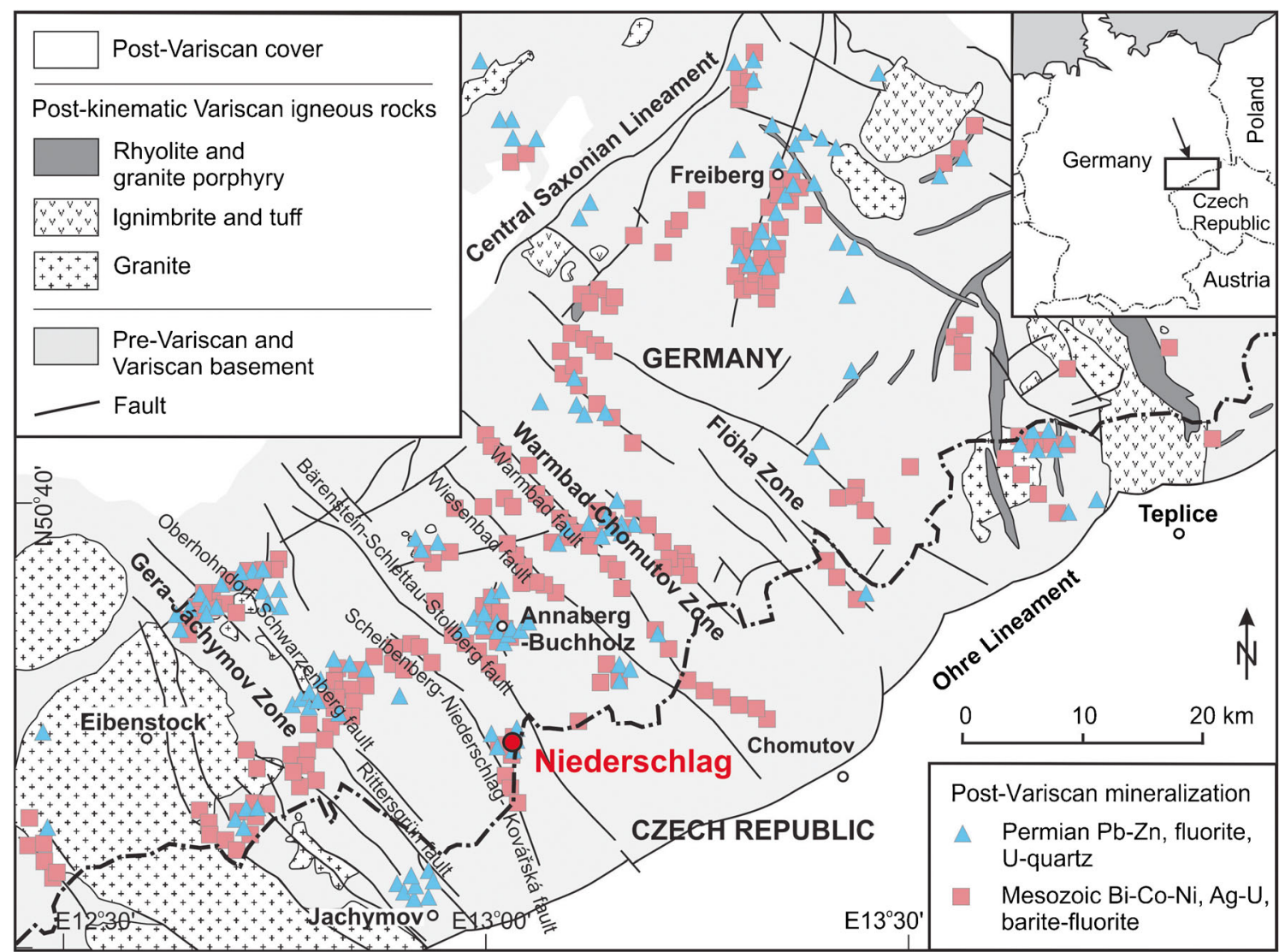

Fig. 1 Map of the major fault zones in the central Erzgebirge (Czech: Krušné Hory) according to Hösel (1972), Leonhardt (1995) and Kuschka et al. (2002). Localities of Post-Variscan mineralisation and their general classification is according to Romer et al. (2010)

the late-Variscan (Permian) to recent times. According to Kuschka et al. (2002), the major fluorite-forming stages dominating the lower part of the Magistralnaya comprise the Permian fluorite-quartz stage and the Mesozoic haematite-barite and barite-fluorite stages (Fig. 3). The classification bases on visual identification of mineral paragenesis. Haschke et al. (2021) proposed a two-stage formation of the deposit based on fluid inclusion and fluorite composition studies. These authors suggest that the haematite-barite and barite-fluorite stages should be considered as one stage, stage II, due to similar origin and chemistry of the ore-forming fluids. The entire mineralisation underwent intense syn- to post-genetic shearing, and in the Paleogene-Neogene, several phonolite dykes and sills intruded the deposit to cause local hydrothermal alteration and replacements (Kuschka et al. 2002). The wall rocks within the mine and below are amphibolite-facies two-mica gneisses and muscovite schists of the Preßnitz Supergroup (Rusová and Měděnec Formation) and of the younger Niederschlag Supergroup. Protoliths of these rocks are Neoproterozoic greywackes (c. 570-540 Ma) with interlayered conglomerates, carbonates and extrusive rhyolites. The entire sequence was metamorphosed under MP-MT conditions during the Variscan orogeny (c. $340 \mathrm{Ma}$; e.g. Tichomirova 2003). The foliation in the schists and gneisses plunges 10 to $35^{\circ} \mathrm{SW}$. More information about the geological setting of the deposit is provided by Haschke et al. (2021).

\section{Results}

\section{Refined characterisation of the Niederschlag barite- fluorite mineralisation}

The visual identification of the fluorite-quartz (stage I according to Haschke et al. 2021) and haematite-barite and barite-fluorite (stage II according to Haschke et al. 2021) assemblages during ongoing underground mining is mainly based on the scheme for vein-type mineralisation in the central Erzgebirge introduced by Kuschka et al. (2002), which is a comprehensive synthesis of earlier works by Baumann (1967, 1968), Baumann and Rösler (1967), Rösler and Pilot (1967) and Kuschka (1972, 1994), and observations made during active mining in the Erzgebirge before 1990. In the following years, however, the skills to identify the different vein 


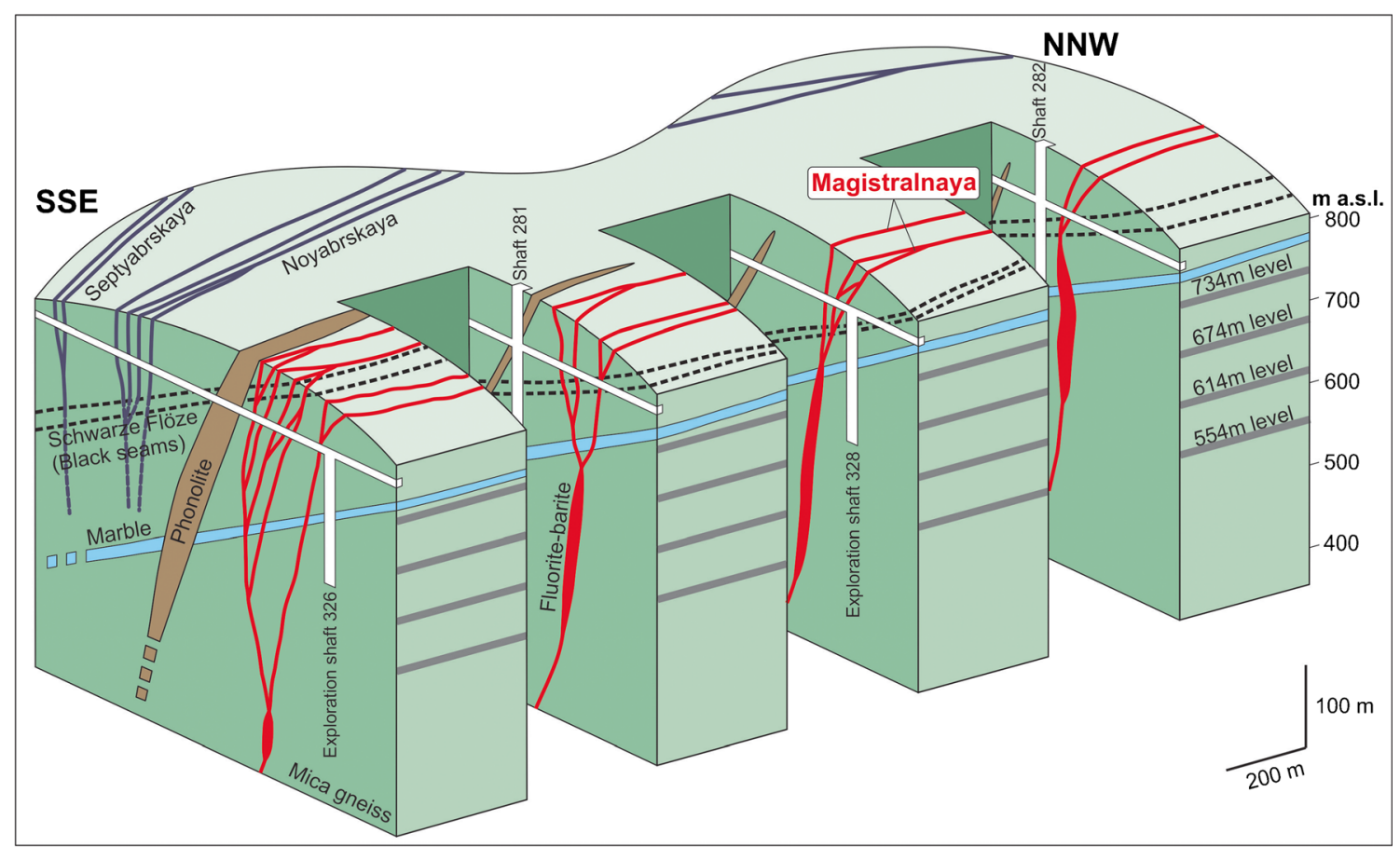

Fig. 2 Block diagram of the Niederschlag barite-fluorite deposit. The barite-fluorite mineralisation (Magistralnaya) is shown in red. The tunnels and shafts shown in white are from the Russian U mining period (19481954), and thick grey lines correspond to current and planned major mining levels. Schwarze Flöze (Black seams) is a mining term referring to sheets ( 0.1 to $2 \mathrm{~m}$ in thickness) of black schist containing accessory graphite and pyrite. With permission of EFS

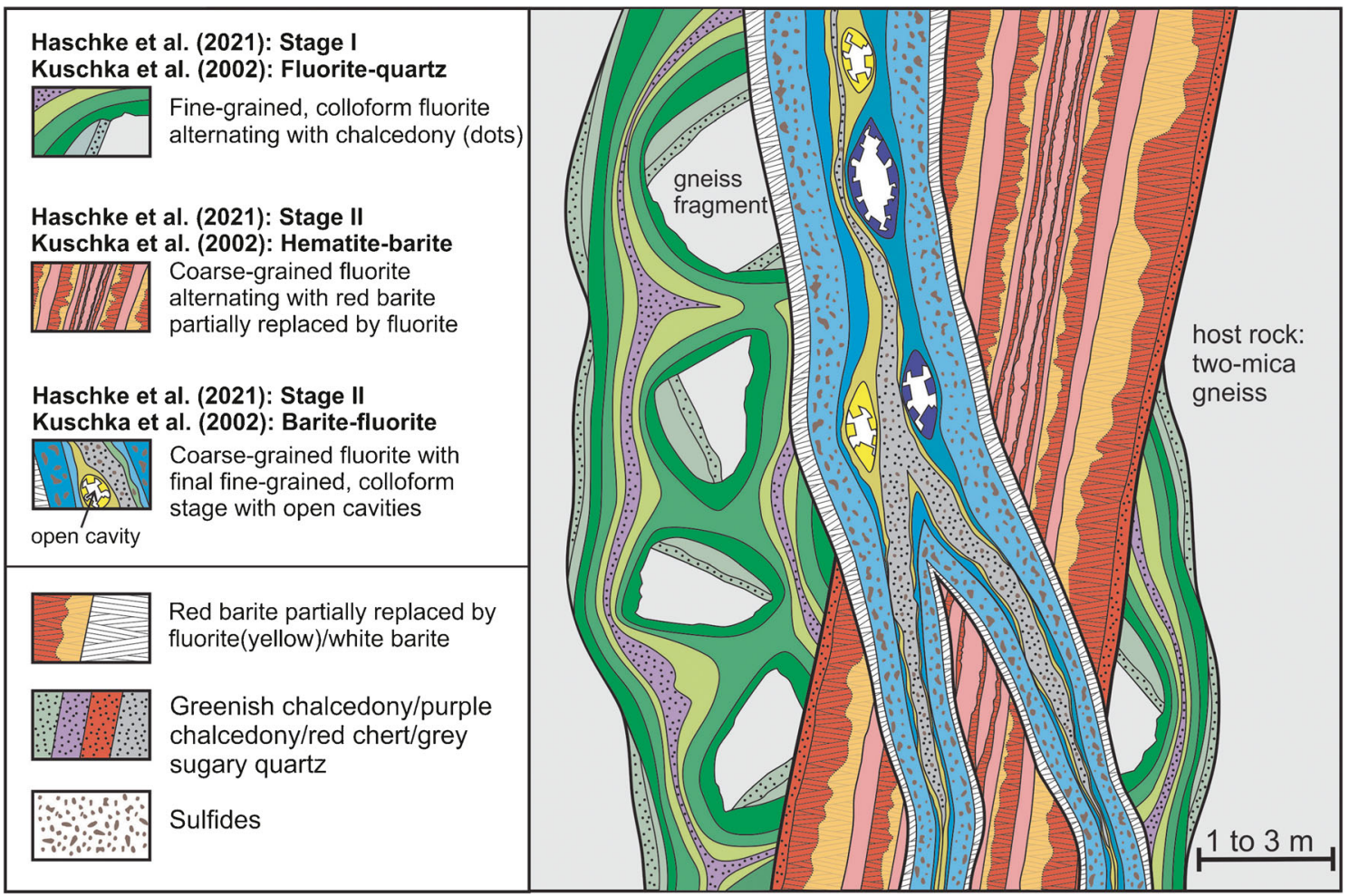

Fig. 3 Simplified scheme for the juxtaposition of the three major fluoritemineralising generations which make up the Niederschlag deposit, as observed at 662-m to 682-m mine levels (c. 120 to $140 \mathrm{~m}$ below surface).
The chosen colours correspond to the dominant fluorite and barite colour in the stage. All stages are associated and overprinted by intense shear tectonics, which are not illustrated due to their complexity 
generations were almost entirely lost. This was until 2013 when the fluorite mine was reopened and new observations were made in combination with a review of the literature and performing new research, such as Haschke et al. (2021). In the following, the haematite-barite and barite-fluorite assemblages are named substages of stage II according to the new findings by Haschke et al. (2021). A new scheme for identifying the different generations is given in Fig. 3 and described below.

The stages and substages are highly distinctive in terms of their mineralogy and textures which requires real-time adjustments of the ore processing depending on the predominant generation in the mined ore (Fig. 3): (1) the fluorite-quartz stage is rich in microfibrous chalcedony with common micro-scale fluorite-chalcedony intergrowths, (2) the haematite-barite substage is rich in haematite-bearing (red) barite and chert ('roter Hornstein') and fine- to micrograined Fe- and Mn-(hydr)oxides and (3) the barite-fluorite substage is rich in sulphides and sugar-textured quartz (Figs. 3 and 4). The primary sulphides in the barite-fluorite substage, which comprise predominantly (in order of abundance) of chalcopyrite, galena and sphalerite, as well as subsidiary tennantite, tetrahedrite, pyrite, marcasite, arsenopyrite and bornite, were commonly altered post-mineralisation, remobilised and precipitated as cerussite, pyromorphite, phosphohedyphane, hemimorphite, mimetite, azurite, malachite, duftite, chrysocolla, etc. These non-fluorite alteration products tend to form smaller mineral grains and aggregate at grain boundaries and in intra-crystal micro fractures which are difficult to remove and therefore may contaminate the concentrate. Figure 4 summarises the main features of the stages and substages with examples of contaminating grains found in the processed fluorite concentrate. Two new observations have been made which require modifications to Kuschka's scheme (Kuschka et al. 2002). Firstly, the haematite-barite substage contains a higher proportion of coarse-grained fluorite (in relation to barite), mainly due to replacement of red barite by late-haematite-barite substage fluorite (fluoritisation; Figs. 3 and 4). Secondly, the main sulphide mineralisation during the barite-fluorite substage began

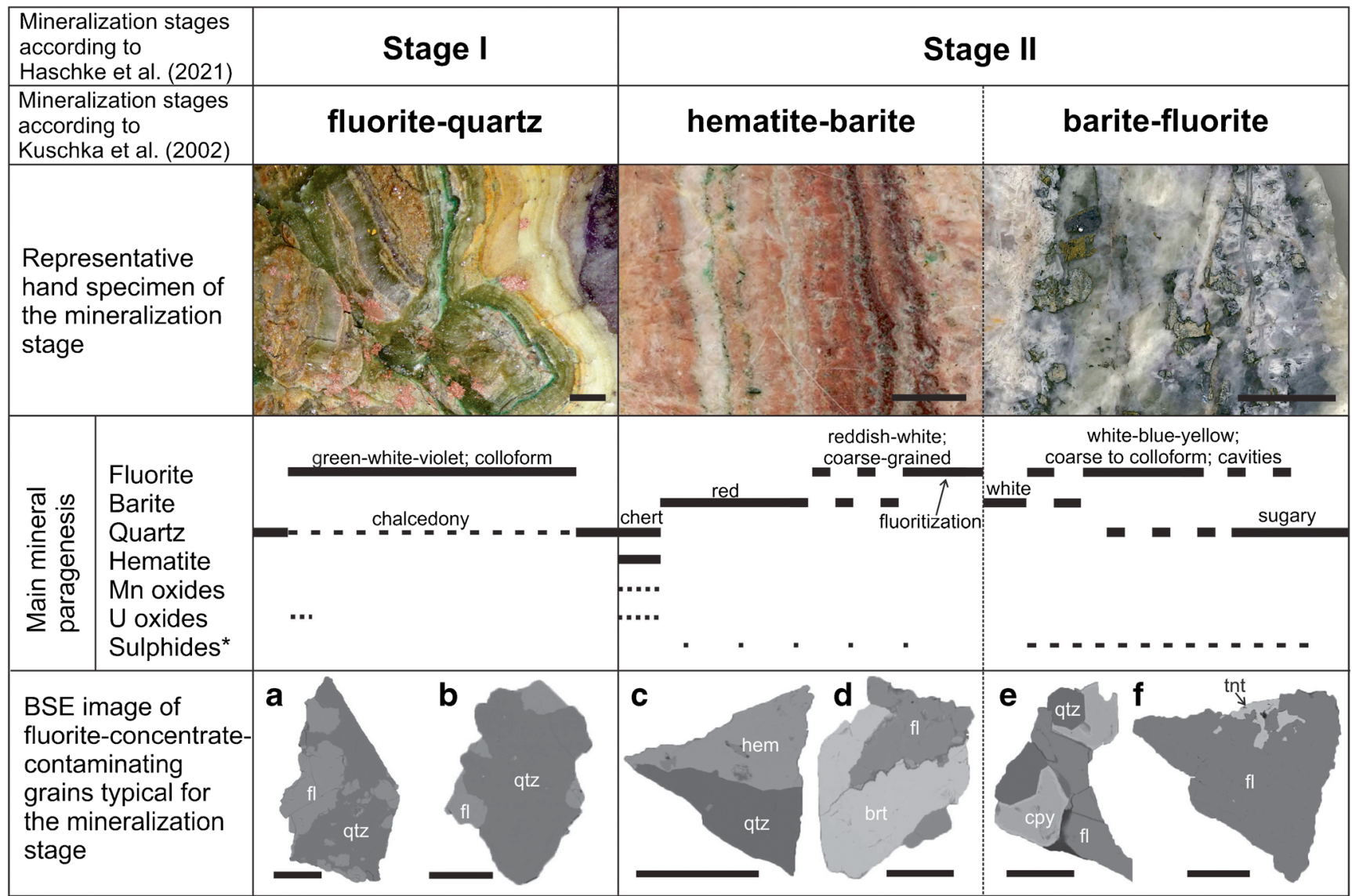

Fig. 4 Characteristics of major fluorite-forming stages of the Niederschlag barite-fluorite deposit, as observed in the 662-m and 682$\mathrm{m}$ levels. Scale bars on the hand specimen photographs correspond to $2 \mathrm{~cm}$ and those on the backscattered electron (BSE) images to $50 \mu \mathrm{m}$. a and b Fluorite (fl) intergrown with chalcedony (qtz); c chert-haematite intergrowth; d fluorite-red barite (brt) intergrowth; e fluoritechalcopyrite(cpy)-sugary quartz intergrowth; f fluorite with tennantite (tnt) inclusions. * primary sulphides: chalcopyrite, galena, sphalerite, tennantite, tetrahedrite, pyrite, marcasite, arsenopyrite and bornite 
after the precipitation of white barite; only a small proportion of the galena seems to be contemporaneous with the crystallisation of white barite.

Volumetric proportions of the three vein generations change vertically and horizontally within the mineralised zone. Thus, their identification and visual and photographic estimation of their proportions within the run-of-mine are essential for successful processing.

\section{Trace element chemistry of fluorite}

Fluorite from all stages has low trace element concentrations in particular for the rare earth elements (REE) (Table 1) compared with fluorite from other deposits (e.g. Schwinn and Markl 2005). Values for $\Sigma$ REE are $54 \pm 30 \mathrm{ppm}$ for flq, $133 \pm 48 \mathrm{ppm}$ for the haematitebarite substage and $75 \pm 24 \mathrm{ppm}$ for the barite-fluorite substage. Distinct differences between these fluorites are as follows: (1) low Y, light (L)REE and middle (M)REE and high $\mathrm{Sr}$ of the fluorite-quartz stage; (2) elevated concentrations of $\mathrm{Y}$, LREE and $\mathrm{Na}$ of the haematite-barite substage; and (3) very low LREE of the barite-fluorite substage (Fig. 5). Some of the haematite-barite substage fluorites (named barite-fluorite late in Fig. 5c) inherited the $\mathrm{Tb} / \mathrm{La}$ ratio and the REE pattern of the older fluoritequartz generation as a result of their partial replacement/ reworking. The majority of fluorite has a hydrothermal signature according to the $\mathrm{Tb} / \mathrm{Ca} *$ versus $\mathrm{Tb} / \mathrm{La}$ discrimination diagram of Möller et al. (1976). The haematitebarite substage fluorite, which plots across the boundary into the pegmatitic field, close to the fluorite-quartz stage fluorites, partially inherited the trace element signature of fluorite-quartz stage fluorites.

In the chondrite-normalised REE plots on Fig. 5c, two types of pattern can be distinguished: (1) those with an enrichment of LREE compared to heavy (H)REE with negative $\mathrm{Ce}$ and $\mathrm{Eu}$ anomalies (fluorite-quartz stage, late haematite-barite substage) and (2) patterns showing a strong depletion in LREE and enrichment of MREE with less pronounced negative $\mathrm{Ce}$ and $\mathrm{Eu}$ anomalies (early haematite-barite and baritefluorite substages). The occurrence of Ce anomalies in REE patterns for fluorite is rare, restricted to only a few localities worldwide such as the Clara fluorite deposit in Schwarzwald, Germany (Schwinn and Markl 2005).

As illustrated in Fig. 5, the fluorite generations are easily distinguishable from their trace element contents and patterns. The older fluorite-quartz stage fluorites are very different to the younger haematite-barite and barite-fluorite substage fluorites in particular in the REE contents and patterns. These findings confirm the results by Haschke et al. (2021) that fluorite at Niederschlag was formed by two different fluid types: low to medium saline fluids with homogenisation temperatures of $140-180^{\circ} \mathrm{C}$ forming the fluorite-quartz stage and younger high salinity fluids with homogenisation temperatures of $80-120{ }^{\circ} \mathrm{C}$ forming the haematite-barite and baritefluorite substages.

The main processes which control the trace element signatures of hydrothermal fluorite are as follows: (1) leaching of source rocks, (2) $P-T$ evolution of the fluid phase, (3) precipitation paragenesis of fluorite and coexisting phases, (4) fluid mixing and interaction with wall rocks and (5) remobilisation and reprecipitation and/or reworking of pre-existing fluorite (Richardson and Holland 1979; Schwinn and Markl 2005). The REE patterns of fluorites from the Niederschlag deposit are mostly controlled by their source rocks as evidenced by the fluorite-quartz stage fluorite having a distinct granite source pattern characterised by an enrichment of HREE and a negative $\mathrm{Eu}^{*}$ anomaly. Their REE pattern is very similar to early-stage granites of the Eibenstock-Nejdek and Kirchberg plutons in the Western Erzgebirge (e.g. Breiter et al. 1999) and to the Altenberg-Frauenstein microgranite and Teplice rhyolite of the Eastern Erzgebirge (e.g. Müller and Seltmann 2002; Müller et al. 2018). Granite xenoliths found in the Paleogene-Neogene phonolith dykes crosscutting the Niederschlag mineralisation indicate the existence of a hidden granite intrusion at greater depth, below the deposit. The negative $\mathrm{Ce}$ anomaly is the only feature which distinguishes the fluorite-quartz stage fluorite pattern from granite REE patterns. The $\mathrm{Ce}$ anomaly resulted from Ce loss from the fluorite-forming fluid during migration, which may have been due to a higher reactivity of $\mathrm{Ce}$ and greater potential to adsorb to surfaces due to its increased oxidation stage compared with the other REEs. The REE patterns of the haematite-barite and barite-fluorite fluorite generations predominantly reflect the composition of the fluids from which they precipitated, which were controlled by varying interactions/equilibration with surrounding metamorphic rocks.

\section{Mining and processing implications}

In this study, we provide a practical guide for the rapid/ real-time identification of the main vein generations in mined ore from the Niederschlag barite-fluorite deposit. The visual classification of the vein generations is based primarily on the scheme for the central Erzgebirge introduced by Kuschka et al. (2002). New identification criteria are established by combining literature data with observations made since the opening of the Niederschlag fluorite mine in 2013 and by including new results on the deposit genesis by Haschke et al. (2021).

Variations in the volumetric proportions of the three vein generations during mining change the types and 
Table 1 Average trace element concentrations (in ppm) of fluorite of different mineralisation stages determined by LA-ICPMS

\begin{tabular}{|c|c|c|c|c|c|c|}
\hline Haschke et al. (2021) & \multicolumn{2}{|l|}{ Stage I } & \multicolumn{2}{|l|}{ Stage II } & \multicolumn{2}{|l|}{ Stage II } \\
\hline \multirow[t]{2}{*}{ Kuschka et al. (2002) } & \multicolumn{2}{|c|}{$\begin{array}{l}\text { Fluorite-quartz } \\
n=24\end{array}$} & \multicolumn{2}{|c|}{$\begin{array}{l}\text { Haematite-barite } \\
n=8\end{array}$} & \multicolumn{2}{|c|}{$\begin{array}{l}\text { Barite-fluorite } \\
n=7\end{array}$} \\
\hline & Mean & STD & Mean & STD & Mean & STD \\
\hline $\mathrm{Na}$ & 48.7 & 22.4 & 209.9 & 133.4 & 52.2 & 25.6 \\
\hline $\mathrm{Mn}$ & $<0.2$ & - & 0.9 & 0.8 & 0.4 & 0.2 \\
\hline $\mathrm{Sr}$ & 214.0 & 46.1 & 157.8 & 103.8 & 142.2 & 60.6 \\
\hline $\mathrm{Y}$ & 22.0 & 17.3 & 231.1 & 106.7 & 173.8 & 54.8 \\
\hline $\mathrm{Zr}$ & $<0.1$ & - & 0.7 & 0.7 & 0.5 & 0.7 \\
\hline $\mathrm{Ba}$ & 0.2 & 0.1 & 2.7 & 2.3 & 0.9 & 0.8 \\
\hline $\mathrm{La}$ & 15.9 & 9.4 & 14.6 & 14.4 & 2.4 & 1.3 \\
\hline $\mathrm{Ce}$ & 10.3 & 13.4 & 26.8 & 24.5 & 5.6 & 2.3 \\
\hline $\operatorname{Pr}$ & 3.5 & 2.0 & 4.7 & 4.1 & 1.4 & 0.6 \\
\hline $\mathrm{Nd}$ & 15.9 & 7.8 & 25.7 & 20.4 & 9.2 & 3.9 \\
\hline $\mathrm{Sm}$ & 2.5 & 1.1 & 8.2 & 3.2 & 5.5 & 1.8 \\
\hline $\mathrm{Eu}$ & 0.4 & 0.2 & 2.0 & 0.6 & 1.6 & 0.6 \\
\hline $\mathrm{Gd}$ & 1.9 & 1.0 & 13.9 & 5.5 & 12.2 & 4.4 \\
\hline $\mathrm{Tb}$ & 0.2 & 0.2 & 2.5 & 1.3 & 2.3 & 0.9 \\
\hline Dy & 1.6 & 1.2 & 17.2 & 9.3 & 16.8 & 7.8 \\
\hline Но & 0.3 & 0.2 & 3.0 & 1.4 & 3.4 & 1.4 \\
\hline $\mathrm{Er}$ & 0.9 & 0.7 & 7.8 & 4.1 & 7.6 & 3.1 \\
\hline $\mathrm{Tm}$ & 0.1 & 0.1 & 0.9 & 0.4 & 1.0 & 0.5 \\
\hline $\mathrm{Yb}$ & 1.0 & 0.8 & 4.8 & 1.9 & 5.5 & 2.6 \\
\hline $\mathrm{Lu}$ & 0.1 & 0.1 & 0.6 & 0.2 & 0.6 & 0.3 \\
\hline $\mathrm{Pb}$ & 0.8 & 0.9 & 6.3 & 6.3 & 5.4 & 7.2 \\
\hline $\mathrm{U}$ & 0.9 & 0.8 & 0.6 & 1.1 & 0.3 & 0.3 \\
\hline LREE & 45.5 & 28.4 & 71.8 & 62.6 & 18.5 & 7.8 \\
\hline MREE & 4.7 & 2.2 & 24.0 & 8.0 & 19.4 & 6.5 \\
\hline HREE & 4.3 & 3.2 & 36.9 & 18.4 & 37.2 & 16.2 \\
\hline$\Sigma$ REE & 54.4 & 29.9 & 132.7 & 47.6 & 75.1 & 24.0 \\
\hline $\mathrm{Eu} / \mathrm{Eu}^{*}$ & 0.46 & 0.06 & 0.56 & 0.06 & 0.60 & 0.10 \\
\hline
\end{tabular}

Concentrations of $\mathrm{Al}, \mathrm{Cu}$ and $\mathrm{K}$ are below the limits of detection, which are 120, 0.6 and $5.5 \mathrm{ppm}$, respectively. $n$ number of analyses, STD standard deviation proportions of mineral phases contaminating the fluorite concentrate. The main contaminating phases are microscale fluorite-chalcedony ingrowths in the fluorite-quartz stage, barite-fluorite intergrowths and $\mathrm{Fe}$ and $\mathrm{Mn}$ (hydr)oxide inclusions in fluorite from the haematitebarite substage, and fluorite- and barite-quartz intergrowths, inclusions of sulphides and their alteration products in fluorite from the barite-fluorite substage. In order to produce the highest quality of fluorite concentrate, the processing has to be continuously adjusted to the mineralogical composition of the mined ore.

LA-ICP-MS is a useful tool for distinguishing fluorite generations from their trace element contents and allows conclusions to be made as to the source of the mineralising fluids. It also adds to our understanding of the nature and genesis of the Niederschlag deposit which may aid in the exploration and discovery of similar such deposits close by or in other geological terranes. Visual observations confirm the existence of three fluorite mineralisation stages and substages supposed by Kuschka et al. (2002). Differences in REE patterns of the Permian quartz-fluorite stage fluorites, indicating a fluid source with granitic fingerprint, and the Mesozoic haematite-barite and barite-fluorite substage fluorites, reflecting an increasing interaction/equilibration with the metamorphic wall rocks, verify the two-stage source model of fluids by Haschke et al. (2021) for the Niederschlag barite-fluorite mineralisation. 

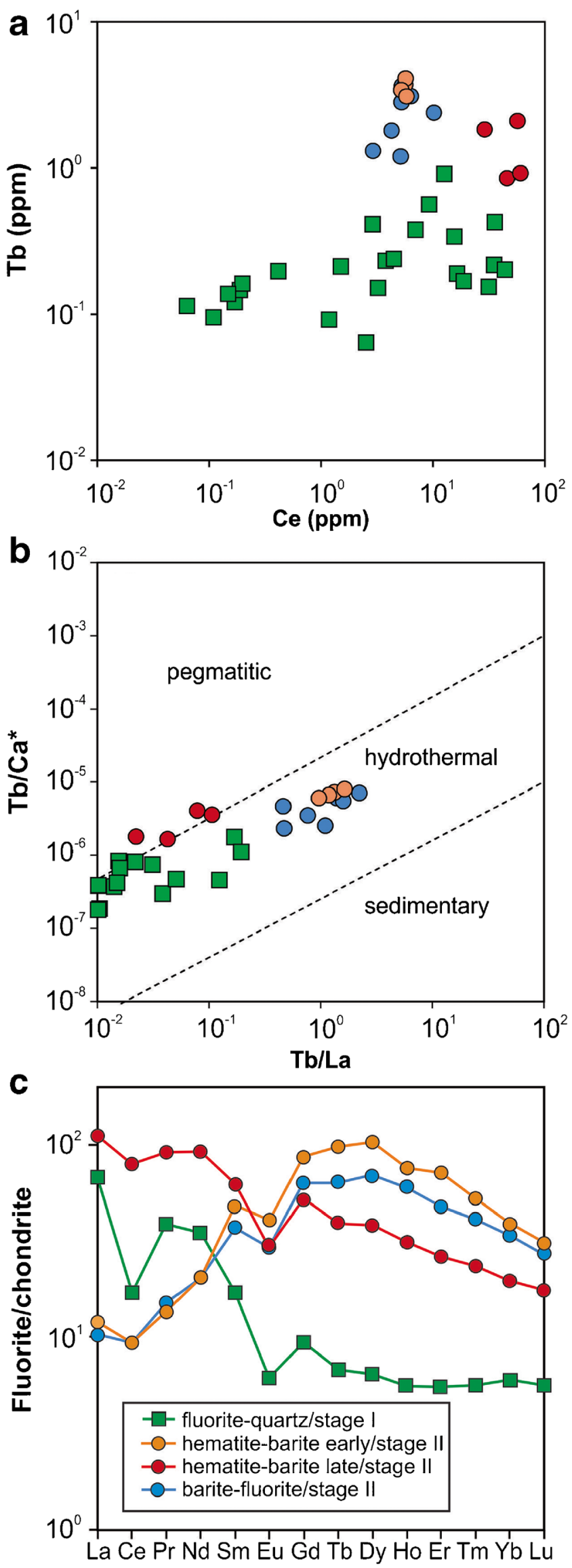

Fig. 5 Trace element variation plots for fluorite from the Niederschlag barite-fluorite deposit. a $\mathrm{Ce}$ versus $\mathrm{Tb}$ diagram for discrimination of the fluorite-forming stages of the Niederschlag deposit. $\mathbf{b ~ T b} / \mathrm{Ca}$ * versus $\mathrm{Tb} /$ La discrimination plot for fluorite according to Möller et al. (1976). Ca*, stoichiometric abundance of $\mathrm{Ca}$ in fluorite. $\mathbf{c}$ Chondrite-normalised REE pattern fluorite. Average concentrations of the different fluorite concentrations are plotted. REE chondrite values used are from Anders and Grevesse (1989)

Acknowledgements We gratefully acknowledge the logistic support from the Erzgebirgische Fluss- und Schwerspatwerke GmbH. The authors would like to acknowledge in particular Matthias Friedrich, the processing manager of EFS, who provided information about processing and mineralogy of the fluorite concentrate. We would like to express our great appreciation to Ben Williamson who contributed substantially to the improvement of the manuscript quality.

Data availability All data related to the study are accessible.

\section{Compliance with ethical standards}

Conflict of interest The authors declare that they have no conflict of interest.

Code availability Not applicable.

Open Access This article is licensed under a Creative Commons Attribution 4.0 International License, which permits use, sharing, adaptation, distribution and reproduction in any medium or format, as long as you give appropriate credit to the original author(s) and the source, provide a link to the Creative Commons licence, and indicate if changes were made. The images or other third party material in this article are included in the article's Creative Commons licence, unless indicated otherwise in a credit line to the material. If material is not included in the article's Creative Commons licence and your intended use is not permitted by statutory regulation or exceeds the permitted use, you will need to obtain permission directly from the copyright holder. To view a copy of this licence, visit http://creativecommons.org/licenses/by/4.0/.

\section{References}

Anders E, Grevesse N (1989) Abundances of the elements: meteoritic and solar. Geochim Cosmochim Acta 53:197-214

Baumann L (1967) Zur Frage der variszischen and postvariszischen Mineralisation im Sächsischen Erzgebirge. Freiberger Forschungsh C209:15-39

Baumann L (1968) Die Mineralparagenesen des Erzgebirges Charakteristik und Genese. Freiberger Forschungsh C230:217-233

Baumann L, Rösler HJ (1967) Zur genetischen Einstufung variszischer und postvariszischer Mineralisationen in Mitteleuropa. Bergakademie 19:660-664

Breiter K, Förster H-J, Seltmann R (1999) Variscan silicic magmatism and related tin-tugnsten mineralization in the ErzgebirgeSlavkovský les metallogenetic province. Miner Depos 34:505-521

European Commission (2017) Report on the 2017 list of critical raw materials for the EU. https://eur-lex.europa.eu/legal-content/EN/ TXT/?uri=CELEX:52017DC0490. Accessed 27 October 2018

Haschke S.S., Gutzmer, J., Wohlgemuth-Ueberwasser, C.C., Kraemer, D., Burisch, M. (2021) The Niederschlag fluorite-(barite) deposit, 
Erzgebirge/Germany - a fluid inclusion and trace element study. Mineralium Deposita, this volume

Hösel G (1972) Position, Aufbau sowie tektonische Strukturen des Erzgebirges. Geologie 29:437-456

Kuschka E (1972) Egebnisse einer Neubearbeitung hydrothermaler Gangmineralisationen des Erzgebirges, Granulitgebirges und Vogtlandes. Z Angew Geol 18:97-108

Kuschka E (1994) Zur Mineralisation und Mineralogie der hydrothermalen Mineralgänge des Vogtlandes, Erzgebirges und Granulitgebirges. Dissertation, TU Bergakademie Freiberg, Germany

Kuschka E, Leonhardt D, Hiller A (2002) Die Uranerz-Baryt-FluoritLagerstätte Niederschlag bei Bärenstein und benachbarte Erzvorkommen. Bergbau in Sachsen 6, Sächsisches Landesamt für Umwelt und Geologie, Dresden, Germany

Leonhardt D (1995) Geologische Karte des Freistaates Sachsen 1 : 400, 000. Sächsisches Landesamt für Umwelt und Geologie, Freiberg, Germany

Möller P, Parekh PP, Schneider H-J (1976) The application of the Tb/Ca$\mathrm{Tb} / \mathrm{La}$ abundance ratios to problems of fluorspar genesis. Miner Depos 11:111-116

Müller A, Seltmann R (2002) Plagioclase-mantled K-feldspar in the Carboniferous porphyritic microgranite of Altenberg-Frauenstein, Eastern Erzgebirge/Krušné Hory. Bull Geol Soc Finland 74:53-79
Müller A, Herklotz G, Giegling H (2018) Chemistry of quartz related to the Zinnwald/Cínovec Sn-W-Li greisen-type deposit, Eastern Erzgebirge, Germany. J Geochem Explor 190:357-373

Richardson CK, Holland HD (1979) Fluorite deposition in hydrothermal systems. Geochim Cosmochim Acta 43/8: 1327-1335

Romer R, Schneider J, Linnemann U (2010) Post-Variscan deformation and hydrothermal mineralization in Saxo-Thuringia and beyond: a geochronological review. In: Romer R (ed) Linnemann U. PreMesozoic geology of Saxo-Thuringia - From the Cadomian Active Margin of the Variscan Orogen. Schweizerbart, Stuttgart, pp 347-370

Rösler HJ, Pilot J (1967) Die zeitliche Einstufung der sächsischthüringischen Ganglagerstätten mit Hilfe der K-Ar-Methode. Freiberger Forschungsh C209:87-98

Schwinn G, Markl G (2005) REE systematics in hydrothermal fluorite. Chem Geol 216:225-248

Tichomirova M (2003) Die Gneise des Erzgebirges - hochmetamorphe Äquivalente von neoproterozoisch-frühpaläozoischen Grauwacken und Granitoiden der Cadomiden. Freiberger Forschungsh C495:1222

Publisher's note Springer Nature remains neutral with regard to jurisdictional claims in published maps and institutional affiliations. 